\title{
Influence of Elevated Temperature and Pressure on Treatment of Landfill Leachate by Potassium Ferrate(VI)
}

\author{
Maciej Thomas (D.) Przemysław Drzewicz • \\ Angelika Więckol-Ryk • \\ Balamurugan Panneerselvam
}

Received: 3 August 2021 / Accepted: 13 October 2021 / Published online: 26 October 2021

(C) The Author(s) 2021

\begin{abstract}
The significant problem is the treatment of landfill leachate characterized by high chemical oxygen demand (COD) and total organic carbon (TOC) and presence of biodegradation inhibitors such as heavy metals and oily substances. For the case of landfill leachate $(\mathrm{pH} 7.9$, color $1550 \mathrm{mg} \mathrm{Pt} / \mathrm{L}$, COD $1880 \mathrm{mg} \mathrm{O}_{2} / \mathrm{L}$, TOC $620 \mathrm{mg} / \mathrm{L}$, total nitrogen (TN) $220 \mathrm{mg} / \mathrm{L}$, total phosphorus (TP) $6 \mathrm{mg} / \mathrm{L}$ and heavy metals), the effect of elevated pressure and temperature on the decrease $\mathrm{COD}$ value by potassium ferrate(VI) $\left(\mathrm{K}_{2} \mathrm{FeO}_{4}\right)$ was investigated. Taguchi method (TM) was employed for optimizing the treatment process parameters (repetition, $\mathrm{pH}, \mathrm{K}_{2} \mathrm{FeO}_{4}$ concentration, time, temperature, and pressure). Maximizing the criterion function of signal-to-noise $(\mathrm{S} / \mathrm{N})$, the optimal parameters were determined: $\mathrm{pH} 3.5, \mathrm{~K}_{2} \mathrm{FeO}_{4} 2.0 \mathrm{~g} / \mathrm{L}$, time $45 \mathrm{~min}$, temperature
\end{abstract}

M. Thomas $(\bowtie)$

Faculty of Environmental and Power Engineering, Cracow University of Technology, 31-155 Kraków, Poland

e-mail: maciej.thomas@pk.edu.pl

P. Drzewicz

Polish Geological Institute National Research Institute, 00-975 Warszawa, Poland

A. Więckol-Ryk

Department of Risk Assessment and Industrial Safety,

Central Mining Institute, 40-166 Katowice, Poland

B. Panneerselvam

Department of Civil Engineering, M. Kumarasamy

College of Engineering, 639113 Karur, Tamil Nadu, India
$30{ }^{\circ} \mathrm{C}$, and pressure of $1 \mathrm{MPa}$. At optimal conditions, a decrease of color, COD, TOC, and TP was above $91 \%$. Additionally, the decrease of $\mathrm{TN}$ was $48.2 \%$. Comparatively, at atmospheric pressure (0.1013 MPa) and at $19{ }^{\circ} \mathrm{C}$, the decrease of color, COD, TOC, TP, and TN was $99.9 \%, 83.0 \%, 79.0 \%, 19.1 \%$, and $100 \%$, respectively. Addition of potassium ferrate(VI) may improve organic compound removal and decreases energy consumption in subcritical water oxidation.

Keywords Landfill leachate $\cdot$ Potassium ferrate(VI) · Taguchi's method · Green oxidizer · Optimization

\section{Introduction}

The treatment of wastewater characterized by high chemical oxygen demand (COD) and low biological oxygen demand $\left(\mathrm{BOD}_{5}\right)$ is a challenging problem (Andreozzi et al., 1999). Due to low biodegradability of organic pollutants and their frequently occurring high toxicity, biological treatment of such wastewater is often ineffective. Treatment by advanced oxidation processes (AOPs) such as Fenton reaction, ozone, or UV-based processes is also ineffective due to high concentration of the pollutants present in the wastewater and their oxidative recalcitrance (Andreozzi et al., 1999). Additionally, a presence of inorganic radical scavengers, mainly carbonate and chloride, 
additionally decreased pollutant removal in AOPs (Drzewicz et al., 1999; Jankowska et al., 2004). It seems that only highly energy-intensive oxidation processes such as ionizing radiation ( $\gamma$-radiation, electron beam irradiation, EBI), electric discharge (electrohydraulic cavitation), hydraulic cavitation, and supercritical water oxidation (SCWO) processes are capable to remove organic pollutants from wastewater (Drzewicz et al., 2004; Locke et al., 2006; Marrone, 2013; Carpenter et al., 2017; Takeuchi \& Yasuoka, 2021; Wei et al., 2021). During the course of these processes, the high concentrations of numerous reactive species that very effectively decompose organic pollutants are obtained in a very short time. Additionally, physical conditions (high temperature and pressure) associated with the processes favor decomposition of refractory compounds. However, in comparison to other AOP, SCWO processes seem to be economically feasible, mainly, due to the application of microwave radiation that allows to deliver effectively high amount of energy (heat) to the treated wastewater in a very short time (Marrone, 2013; Serpone et al., 2010; Wei et al., 2021). SCWO processes require temperature above $374{ }^{\circ} \mathrm{C}$ and pressure above 22.1 MPa; therefore, various catalysts are frequently used in SWCO in order to improve economical parameters by reducing the operating parameters, i.e., temperature, pressure, and reaction time. (Jing et al., 2016; Sushma \& Saroha, 2018). However, application of catalysts triggers additional problem related to catalyst deterioration and its recovery after the process (Jing et al., 2016; Keav et al., 2011). Addition of green oxidant that decompose to non-harmful products, e.g., ozone, $\mathrm{H}_{2} \mathrm{O}_{2}$, or magnetic nanoparticles of metallic iron or iron oxides, may also alleviate the operating conditions and improve pollutant removal efficiency (Drzewicz et al., 2012; Kirmizakis et al., 2014; Scandelai et al., 2018). Landfill leachate is dark colored aqueous effluent formed as a result of rainwater percolation through the landfill, during which the pollutants are transferred from the wastes to the percolating water (Kulikowska \& Klimiuk, 2008). The leachate is characterized by low $\mathrm{BOD}_{5} / \mathrm{COD}$ ratio, which decreases with the age, and fairly high ammonia nitrogen $\left(\mathrm{N}_{\mathrm{NH} 4}\right)$ and heavy metal content (Kulikowska \& Klimiuk, 2008; Renou et al., 2008). Conventional leachate treatment methods, such as air stripping, coagulation, flocculation, and settling, are often costly in terms of initial outlay of plant equipment, energy requirements, and frequent use of additional chemicals (Abbas et al., 2009; Renou et al., 2008; Wiszniowski et al., 2006). Other methods such as reverse osmosis and active carbon adsorption only transfer the pollution and do not solve the environmental problems. The biological processing of leachate needs, in most cases, large areas to run with the additional disadvantage of generating large amounts of sludge. AOPs, e.g., Fenton process $\left(\mathrm{Fe}(\mathrm{II})+\mathrm{H}_{2} \mathrm{O}_{2}\right.$ ), photo-Fenton process ( $\left.\mathrm{Fe}(\mathrm{II})+\mathrm{H}_{2} \mathrm{O}_{2}+\mathrm{UV}\right)$, UV/ $\mathrm{H}_{2} \mathrm{O}_{2}, \mathrm{UV} / \mathrm{O}_{3}$, and $\mathrm{UV} / \mathrm{TiO}_{2}$, have been proposed in the recent years as an effective alternative for mineralization of recalcitrant organics in landfill leachate (Gautam et al., 2019). However, these methods in application for the treatment of large-scale effluents are not economically feasible (Abbas et al., 2009; Wiszniowski et al., 2006). Combination of physical, chemical, and biological processes is frequently proposed for treatment of landfill leachate; however, economic feasibility of such solution has not been proved yet (Keyikoglu et al., 2021; Luo et al, 2020a, 2020b). SCWO is another method proposed for treatment of landfill leachate (Wang et al., 2011). However, high temperature and pressure (significantly higher than $374{ }^{\circ} \mathrm{C}$ and $22.1 \mathrm{MPa}$ ) leads to gasification of organic matter and precipitation of inorganic salts (Ferreira Pinto et al., 2017). Moreover, corrosion is a key barrier that limits commercial applications of SCWO (Adar et al., 2019). Corrosion problems in SCWO are caused by high temperature and sharp pressure changes, high content of undissolved oxygen, the solubility of gases, high $\mathrm{pH}$ value, and formation of chemically aggressive decomposition products. Therefore, the oxidation process in landfill leachate is conducting below supercritical point of water (Kirmizakis et al., 2014; Zhai et al., 2016). So-called wet air oxidation (WAO) is conducted in temperature from above $100{ }^{\circ} \mathrm{C}$ and above atmospheric pressure to near below supercritical water condition (Kolaczkowski et al., 1999). The green oxidant, e.g., $\mathrm{H}_{2} \mathrm{O}_{2}$, potassium peroxysulfate $\left(2 \mathrm{KHSO}_{5} \times \mathrm{KHSO}_{4} \times \mathrm{K}_{2} \mathrm{SO}_{4}\right)$, potassium persulfate $\left(\mathrm{K}_{2} \mathrm{~S}_{2} \mathrm{O}_{8}\right)$, and ozone $\left(\mathrm{O}_{3}\right)$, is added in order to promote oxidation of organic compounds in landfill leachate (Anglada et al., 2011; Rivas et al., 2005; Xu et al., 2012; Zhai et al., 2016). Potassium ferrate(VI) is an emerging green water treatment agent frequently proposed for wastewater treatment (Wang et al., 2021). The results of recent study has shown that potassium ferrate(VI) can be 
successfully applied also for treatment of landfill leachate (Thomas et al., 2020). Potassium ferrate(VI) may oxidize organic compounds by electron or/and oxygen transfer mechanisms (Rush \& Bielski, 1989; Chen et al., 2018; Luo et al., 2020a, 2020b; Wang et al., 2021). Thus, reactivity of potassium ferrate(VI) depends on $\mathrm{pH}$ value. The formation of many radical species was also observed during the oxidation reactions (Drzewicz et al., 2019). Therefore, one can assumed that increasing reaction temperature results in an increase of potassium ferrate(VI) reactivity. Increasing water temperature improves diffusion of radicals, miscibility of low polar compounds, and hydrolysis of the compounds whereas increasing pressure-solubility of gases such as oxygen (Akiya \& Savage, 2002; Kruse \& Dinjus, 2007; Weingärtner $\&$ Franck, 2005). It was found that, in the presence of oxygen, formed superoxide radicals are involved in oxidation of organic compounds by potassium ferrate(VI) (Drzewicz et al., 2019). As a result, at elevated pressure, an increase of oxygen concentration increases formation of superoxide radicals that are involved in oxidation of organic compounds (Hayyan et al., 2016). Superoxide radical and hydrogen peroxide are not reactive towards ferrate(VI) anions (Rush et al., 1996). Most studies (Sharma et al., 2000; Graham et al., 2004; Li et al., 2005; Jiang et al., 2009; Lan et al., 2014; Moradnia et al., 2016; Lv et al., 2018; Luo et al., 2019; Drzewicz et al., 2019) have only focused on the application of potassium ferrate(VI) under normal temperature and pressure. For this reason, the aim of presented study is to broaden current knowledge of application of $\mathrm{K}_{2} \mathrm{FeO}_{4}$. Thus, it was examined an effect of elevated pressure and temperature on oxidation of organic pollutants in landfill leachate by $\mathrm{K}_{2} \mathrm{FeO}_{4}$ and following coagulation and flocculation process. Taguchi's method was used in planning the experiments and optimization of process conditions as well as determination of the most influential parameters.

\section{Materials and Methods}

\subsection{Materials}

The study used a leachate sample from old municipal waste landfill located in southern Poland. Two municipal landfill leachate samples were collected manually from two drainage wells connected to vertical drainage system. The samples were transported to the laboratory, and then, combined and well mixed. Samples were transported and stored in cool conditions at $4{ }^{\circ} \mathrm{C}$, without any preservation, until the tests were performed. The physicochemical parameters of the leachate sample are given in Table 1

The commercial Envifer ${ }^{\circledR}$ (Nano Iron, s.r.o., Czech Republic) was used as the source of $\mathrm{K}_{2} \mathrm{FeO}_{4}$. Envifer® contained 40 wt. $\%$ of pure $\mathrm{K}_{2} \mathrm{FeO}_{4}$. The detail description of the composition and physicochemical properties of Envifer ${ }^{\circledR}$ is reported elsewhere (Thomas et al., 2018). The $\mathrm{pH}$ value of the samples was adjusted by addition of $25 \mathrm{wt} . \% \mathrm{H}_{2} \mathrm{SO}_{4}$ and $25 \mathrm{wt} \%$ $\mathrm{NaOH}$ (analytical grade, Chempur, Poland). For flocculation, anionic flocculant (polyacrylamide), 0.05 wt.\% solution (technical grade, Furoflock CW 277, Chemische Fabrik Wocklum GmbH \& Co. KG, Germany) was applied. Double distilled water (conductivity $<2 \mu \mathrm{S} / \mathrm{cm}$ ) was used in all experiments. Additionally, synthetic air containing $21 \% \mathrm{O}_{2}$ and $79 \% \mathrm{~N}_{2}$ by volume (analytical grade, Air Liquide Polska Ltd., Poland) was used.

\subsection{Analytical Methods}

The concentration of $\mathrm{K}_{2} \mathrm{FeO}_{4}$ in Envifer ${ }^{\circledR}$ was determined before performing the tests by using two separated methods, i.e., spectrophotometrically and titrimetrically (Schreyer et al., 1950; Thomas et al., 2020; Wei et al., 2015). Determination of $\mathrm{pH}$ value was performed by the use of Inolab ${ }^{\circledR} \mathrm{pH} /$ Ion/Cond 750 and $\mathrm{pH}$ combination electrode with built-in temperature sensor, SenTix ${ }^{\circledR} 81$ (WTW, Germany), according to ISO 10523 (ISO 10523, 2008). The determination of chemical oxygen demand (COD) was performed according to ISO 15705 (ISO 15705, 2002). The methods applied for determination of total organic carbon (TOC), total nitrogen (TN), and total phosphorus (TP) are described in detail elsewhere (Thomas et al., 2020). Chloride was determined by using Mohr's method according to ISO 9297 (ISO $9297,1994)$ and the concentration of sulfate in the landfill leachate was determined by using gravimetric method according to ISO 9280 (ISO 9280, 2002). The determination of selected heavy metals: $\mathrm{Cd}, \mathrm{Cr}, \mathrm{Cu}$, 
$\mathrm{Fe}, \mathrm{Ni}, \mathrm{Pb}$, and $\mathrm{Zn}$ were performed with ICP-OES in accordance with ISO 11885 (ISO 11885, 2007).

\subsection{Optimization by Taguchi’s Method}

The operating parameters of the treatment process were optimized by using Taguchi's method. The software Statistica 13 (Tibco Software Inc., USA) was used to plan and analyze the experimental findings. Taguchi's method was used to find the parameters, which significantly influence the process and are independent from other process variables. The orthogonal array (OA) provides the vast amount of information from the minimum number of experiments. The process output was the decrease of COD in landfill leachate. In the Taguchi design, signal-tonoise $(\mathrm{S} / \mathrm{N})$ ratio is used for variation reduction of process output and optimization of process parameters. Signal-to-noise $(\mathrm{S} / \mathrm{N})$ ratio reflects the deviations of actual process output values from the target output values. "The smaller is better" and $\mathrm{S} / \mathrm{N}$ ratio are the primary factors which help identify the optimal input parameters of the process. The $\mathrm{S} / \mathrm{N}$ ratios were calculated with Eq. 1. $\eta=10 \log _{10}\left(\frac{1}{n} \sum_{t=1}^{n} y_{i}^{2}\right)$

where $i$ is a measurement number, $\eta$ is a $\mathrm{S} / \mathrm{N}$ factor, $n$ is a number of experiments, and $y$ is a response to the given factor level combination (Asghar et al., 2014; Thomas et al., 2018). The orthogonal array $\mathrm{L}_{48}$; five parameters: $\mathrm{pH}$ value $(2.5,3.5,4.5,5.5)$, $\mathrm{K}_{2} \mathrm{FeO}_{4}$ conc. $(0.5,1.0,1.5,2.0 \mathrm{~g} / \mathrm{L})$, time $(15,30$, 45, $60 \mathrm{~min})$, temperature $\left(20,30,40,50{ }^{\circ} \mathrm{C}\right)$, and pressure (1, 2, 3, $4 \mathrm{MPa})$ at four levels each; and the repetitions were designed (Tab. 2).

\subsection{Experimental Set-up}

All oxidation experiments were performed in a high-pressure reactor (Berghof HR-100 Hochdruck Autoklav, Berghof Products + Instruments $\mathrm{GmbH}$, Germany) (see Fig. 1).

The capacity of the stainless steel reactor was $150 \mathrm{~mL}$ and its maximum operating parameters were $10 \mathrm{MPa}$ and $250{ }^{\circ} \mathrm{C}$. The reactor was heated using a dry block heater (BLH-800, Berghof Products + Instruments GmbH, Germany). The sample in the reactor was mixed with a magnetic stirrer.
Table 1 Physicochemical parameters of raw landfill leachate

\begin{tabular}{|c|c|c|}
\hline Parameter & Unit & $\begin{array}{l}\text { Raw landfill lea- } \\
\text { chate } \pm \text { uncertainty } \\
\text { Coverage factor, } \\
\mathrm{k}=2\end{array}$ \\
\hline $\mathrm{pH}$ & - & $7.9 \pm 0.1$ \\
\hline Conductivity & $\mu \mathrm{S} / \mathrm{cm}$ & $10550 \pm 530$ \\
\hline Salinity & $\mathrm{mg} \mathrm{NaCl} / \mathrm{L}$ & $7210 \pm 360$ \\
\hline Color & $\mathrm{mg} \mathrm{Pt} / \mathrm{L}$ & $1550 \pm 310$ \\
\hline Chemical oxygen demand, COD & $\mathrm{mg} \mathrm{O}_{2} / \mathrm{L}$ & $1880 \pm 280$ \\
\hline Total organic carbon, TOC & $\mathrm{mg} / \mathrm{L}$ & $620 \pm 90$ \\
\hline Total nitrogen $(\mathrm{TN})$ & $\mathrm{mg} / \mathrm{L}$ & $220 \pm 30$ \\
\hline Total phosphorus (TP) & $\mathrm{mg} / \mathrm{L}$ & $6.0 \pm 0.9$ \\
\hline Chlorides & $\mathrm{mg} / \mathrm{L}$ & $790 \pm 80$ \\
\hline Sulfates & $\mathrm{mg} / \mathrm{L}$ & $150 \pm 15$ \\
\hline Cadmium & $\mathrm{mg} / \mathrm{L}$ & $0.020 \pm 0.004$ \\
\hline Chromium (total) & $\mathrm{mg} / \mathrm{L}$ & $0.10 \pm 0.02$ \\
\hline Copper & $\mathrm{mg} / \mathrm{L}$ & $0.50 \pm 0.05$ \\
\hline Iron & $\mathrm{mg} / \mathrm{L}$ & $38.0 \pm 3.8$ \\
\hline Nickel & $\mathrm{mg} / \mathrm{L}$ & $0.12 \pm 0.02$ \\
\hline Lead & $\mathrm{mg} / \mathrm{L}$ & $0.25 \pm 0.05$ \\
\hline Zinc & $\mathrm{mg} / \mathrm{L}$ & $14.0 \pm 1.4$ \\
\hline
\end{tabular}


The temperature was adjusted and controlled with an electronic temperature controller. The manometer was used for pressure monitoring. The inlet and outlet valves were used to control the pressure inside the reactor. The pressure was adjusted with synthetic air $21 \% \mathrm{O}_{2}$ and $79 \% \mathrm{~N}_{2}$ by volume (analytical grade, Air Liquide Polska Ltd.). Specified amount of solid $\mathrm{K}_{2} \mathrm{FeO}_{4}( \pm 0.001 \mathrm{~g})$ was placed in the reactor's Teflon vessel, and after that, $100 \mathrm{~mL}$ of landfill leachate was added. The solution was stirred at $200 \mathrm{rpm}$ until the added salt dissolved completely. After adjusting $\mathrm{pH}$ value using 25 wt. $\% \mathrm{H}_{2} \mathrm{SO}_{4}$ or 25 wt. $\% \mathrm{NaOH}$ solution (if a further $\mathrm{pH}$ value correction after addition of $\mathrm{H}_{2} \mathrm{SO}_{4}$ was needed), the reactor was tightly closed and the pressure was adjusted with analytical grade synthetic air from a high-pressure gas cylinder. After that, the reactor was heated to the specified temperature. The increase of pressure during heating was carefully compensated. After the oxidation process, the solution was transferred to a beaker and left for $15 \mathrm{~min}$ to cool down to room temperature. In the next step, the solution was stirred at $200 \mathrm{rpm}$ and the $\mathrm{pH}$ value of the solution was adjusted to $9.5 \pm 0.1$. At these conditions, all amount of iron hydroxide precipitated. Then, $0.2 \mathrm{~mL}$ of $0.05 \mathrm{wt} \%$ anionic flocculant solution was added and the stirring rate was reduced to $50 \mathrm{rpm}$. The stirring was stopped after $10 \mathrm{~s}$ and the solution was left for $5 \mathrm{~min}$, during which time a formed sediment settled at the bottom of the beaker. The sample for analysis of the landfill leachate parameters was taken from the solution above the sediment and filtered through the 0.45- $\mu \mathrm{m}$ PTFE syringe filter. Comparatively, additional experiments were carried out at ambient temperature $\left(19^{\circ} \mathrm{C}\right)$ and atmospheric pressure (0.1013 MPa).

\section{Results and Discussion}

It has been shown that the leachates examined were characterized by a slightly alkaline $\mathrm{pH}$ 7.9, high electrical conductivity $10555 \mu \mathrm{S} / \mathrm{cm}$, and salinity $7210 \mathrm{mg} \mathrm{NaCl} / \mathrm{L}$ as well as an intense brown color $1550 \mathrm{mg} \mathrm{Pt} / \mathrm{L}$ (Tab. 1). The determined values of COD, TOC, and TN indicated a presence of a large concentration of various substances in the analyzed leachates (mainly organic compounds). As it reported earlier, $\mathrm{pH}$ value may change with leachate age. The $\mathrm{pH}$ for young leachate is below 6.5 whereas for mid age is in the range from 6.5 to 7.5 , and for old one is higher than 7.5 (Aziz, 2012; Yadav \& Dikshit, 2017; Tejera et al., 2019). The COD value below $5000 \mathrm{mg}$ $\mathrm{O}_{2} / \mathrm{L}$ and $\mathrm{pH} 7.9$ suggest that samples were collected from an old landfill. The leachates from old landfill are usually characterized by high production of methane and high fraction of organic compounds, mostly humic and fulvic acid fractions (Aziz, 2012; Yadav \& Dikshit, 2017; Tejera et al., 2019). Humic and fulvic acid fraction is hardly removed in biodegradation and AOP processes (Andreozzi et al., 1999). Additionally, the concentration ammonium nitrogen $\left(\mathrm{N}_{\mathrm{NH} 4}\right)$ in such leachate is usually above $400 \mathrm{mg} / \mathrm{L}$. However, TN for investigated leachate samples was $220 \mathrm{mg} / \mathrm{L}$, and nitrate or nitrite nitrogen anions were not detected (detection limit was $0.1 \mathrm{mg} / \mathrm{L}$ ). This value is characteristic for landfill from a young landfill. However, it is important to note that the physicochemical properties of leachate strongly depend also on kind of dumped waste and landfill location (Wang et al., 2018a, 2018b). For example, similar results, pH 7.7, and $290 \mathrm{mg} / \mathrm{L}$ ammonia have been reported for leachates from a landfill located in Jhiri village, Ranchi City, Jharkhand, India (Verma \& Kumar, 2016). Due to high toxicity, ammonium cation hampers biodegradation process (Drzewicz et al., 2004). Moreover, excess amount of oxidant is needed for oxidation of ammonium cation to nitrate anion. Nitrate anion is not toxic and helps in biodegradation of organic matter; however, it causes eutrophication of natural water bodies.

The presence of high concentration of metal is also observed in the investigated leachate samples. The concentrations of metals in the leachates from landfills located in different parts of the world vary for iron in the range from 3.41 (in Matuanil landfill Bangladesh) up to $167.61 \mathrm{mg} / \mathrm{L}$ (in Riyadh City, Saudi Arabia) and for zinc from 0.05 (in Sivas, Turkey) to $17.80 \mathrm{mg} / \mathrm{L}$ (in MSW incineration plants, China). Moreover, the concentration of nickel and cadmium in investigated samples were 0.12 and $0.02 \mathrm{mg} / \mathrm{L}$, respectively. In comparison, for example, the concentrations of nickel and cadmium were from 0.17 (in Matuanil landfill, Bangladesh) to $3.70 \mathrm{mg} / \mathrm{L}$ (in MSW incineration plants, China) (Mojiri et al., 2021). The heavy metals have detrimental effect on environment; thus, the landfill leachate cannot be released to environment without the treatment. Moreover, the 
Table 2 Experimental conditions (factors and levels of the orthogonal array) and results of experiments-concertation $\mathrm{COD}, \mathrm{mg} \mathrm{O}_{2} / \mathrm{L}$ landfill leachate after the treatment

\begin{tabular}{|c|c|c|c|c|c|c|c|}
\hline \multirow[t]{2}{*}{ Run } & \multicolumn{7}{|c|}{ Experimental conditions* } \\
\hline & Repetition & $\mathrm{pH}$ & $\mathrm{K}_{2} \mathrm{FeO}_{4}$ & Time & Temperature & Pressure & $\mathrm{COD}, \mathrm{mg} \mathrm{O}_{2} / \mathrm{L}^{* *}$ \\
\hline 1 & 1 & 1 & 1 & 1 & 1 & 1 & $730 \pm 110$ \\
\hline 2 & 1 & 1 & 2 & 2 & 2 & 2 & $405 \pm 60$ \\
\hline 3 & 1 & 1 & 3 & 3 & 3 & 3 & $215 \pm 30$ \\
\hline 4 & 1 & 1 & 4 & 4 & 4 & 4 & $200 \pm 30$ \\
\hline 5 & 1 & 2 & 1 & 2 & 3 & 4 & $605 \pm 90$ \\
\hline 6 & 1 & 2 & 2 & 1 & 4 & 3 & $380 \pm 60$ \\
\hline 7 & 1 & 2 & 3 & 4 & 1 & 2 & $210 \pm 30$ \\
\hline 8 & 1 & 2 & 4 & 3 & 2 & 1 & $150 \pm 20$ \\
\hline 9 & 1 & 3 & 1 & 3 & 4 & 2 & $650 \pm 100$ \\
\hline 10 & 1 & 3 & 2 & 4 & 3 & 1 & $405 \pm 60$ \\
\hline 11 & 1 & 3 & 3 & 1 & 2 & 4 & $290 \pm 40$ \\
\hline 12 & 1 & 3 & 4 & 2 & 1 & 3 & $210 \pm 30$ \\
\hline 13 & 1 & 4 & 1 & 4 & 2 & 3 & $675 \pm 100$ \\
\hline 14 & 1 & 4 & 2 & 3 & 1 & 4 & $420 \pm 60$ \\
\hline 15 & 1 & 4 & 3 & 2 & 4 & 1 & $260 \pm 40$ \\
\hline 16 & 1 & 4 & 4 & 1 & 3 & 2 & $250 \pm 40$ \\
\hline 17 & 2 & 1 & 1 & 1 & 1 & 1 & $705 \pm 105$ \\
\hline 18 & 2 & 1 & 2 & 2 & 2 & 2 & $395 \pm 60$ \\
\hline 19 & 2 & 1 & 3 & 3 & 3 & 3 & $250 \pm 40$ \\
\hline 20 & 2 & 1 & 4 & 4 & 4 & 4 & $205 \pm 30$ \\
\hline 21 & 2 & 2 & 1 & 2 & 3 & 4 & $615 \pm 90$ \\
\hline 22 & 2 & 2 & 2 & 1 & 4 & 3 & $395 \pm 60$ \\
\hline 23 & 2 & 2 & 3 & 4 & 1 & 2 & $195 \pm 30$ \\
\hline 24 & 2 & 2 & 4 & 3 & 2 & 1 & $150 \pm 20$ \\
\hline 25 & 2 & 3 & 1 & 3 & 4 & 2 & $650 \pm 100$ \\
\hline 26 & 2 & 3 & 2 & 4 & 3 & 1 & $395 \pm 60$ \\
\hline 27 & 2 & 3 & 3 & 1 & 2 & 4 & $275 \pm 40$ \\
\hline 28 & 2 & 3 & 4 & 2 & 1 & 3 & $210 \pm 30$ \\
\hline 29 & 2 & 4 & 1 & 4 & 2 & 3 & $660 \pm 100$ \\
\hline 30 & 2 & 4 & 2 & 3 & 1 & 4 & $420 \pm 60$ \\
\hline 31 & 2 & 4 & 3 & 2 & 4 & 1 & $250 \pm 40$ \\
\hline 32 & 2 & 4 & 4 & 1 & 3 & 2 & $240 \pm 40$ \\
\hline 33 & 3 & 1 & 1 & 1 & 1 & 1 & $695 \pm 100$ \\
\hline 34 & 3 & 1 & 2 & 2 & 2 & 2 & $395 \pm 60$ \\
\hline 35 & 3 & 1 & 3 & 3 & 3 & 3 & $230 \pm 35$ \\
\hline 36 & 3 & 1 & 4 & 4 & 4 & 4 & $185 \pm 30$ \\
\hline 37 & 3 & 2 & 1 & 2 & 3 & 4 & $600 \pm 90$ \\
\hline 38 & 3 & 2 & 2 & 1 & 4 & 3 & $380 \pm 60$ \\
\hline 39 & 3 & 2 & 3 & 4 & 1 & 2 & $200 \pm 30$ \\
\hline 40 & 3 & 2 & 4 & 3 & 2 & 1 & $150 \pm 20$ \\
\hline 41 & 3 & 3 & 1 & 3 & 4 & 2 & $655 \pm 100$ \\
\hline 42 & 3 & 3 & 2 & 4 & 3 & 1 & $405 \pm 60$ \\
\hline 43 & 3 & 3 & 3 & 1 & 2 & 4 & $275 \pm 40$ \\
\hline 44 & 3 & 3 & 4 & 2 & 1 & 3 & $205 \pm 30$ \\
\hline 45 & 3 & 4 & 1 & 4 & 2 & 3 & $685 \pm 100$ \\
\hline
\end{tabular}


Table 2 (continued)

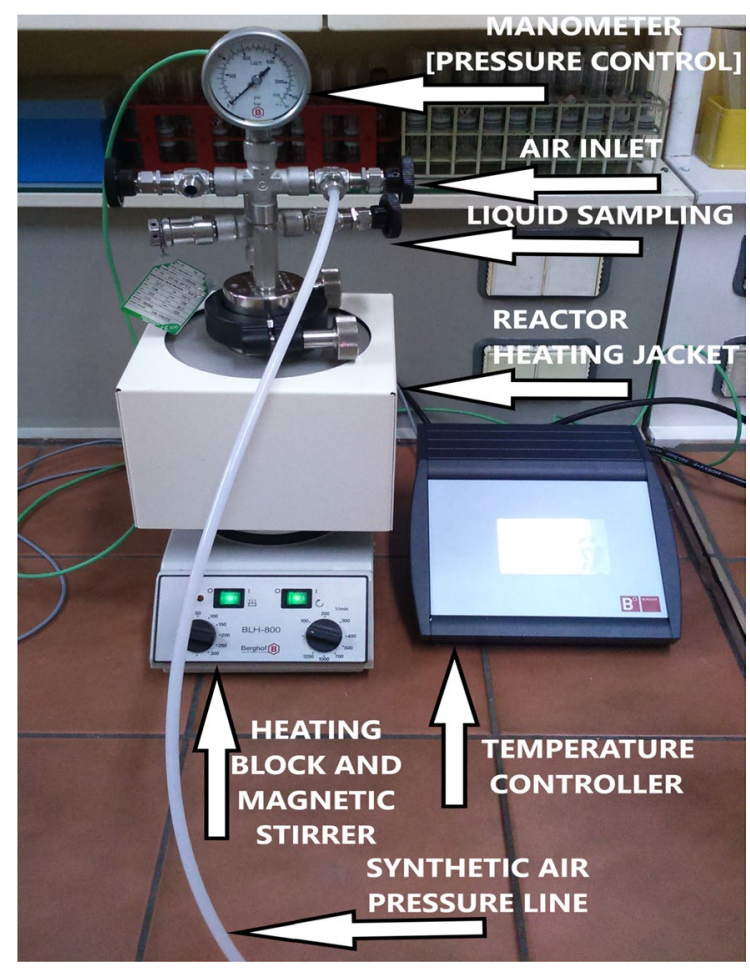

Fig. 1 High-pressure reactor (Berghof HR-100 Hochdruck Autoklav with heating block BLH-800 and temperature controller, Berghof Products + Instruments GmbH, Germany)

*Experimental conditions for $\mathrm{pH}=2.5(1), 3.5$

(2), 4.5 (3), and 5.5 (4); $\mathrm{K}_{2} \mathrm{FeO}_{4}=0.5 \mathrm{~g} / \mathrm{L}(1)$, $1.0 \mathrm{~g} / \mathrm{L}(2), 1.5 \mathrm{~g} / \mathrm{L}(3)$, and $2.0 \mathrm{~g} / \mathrm{L}(4) ;$ time $=15 \mathrm{~min}$

(1), $30 \mathrm{~min}(2), 45 \mathrm{~min}$

(3), and $60 \mathrm{~min}(4)$; temperature $=20^{\circ} \mathrm{C}(1)$, $30{ }^{\circ} \mathrm{C}(2), 40{ }^{\circ} \mathrm{C}$, and $50{ }^{\circ} \mathrm{C}$ (4); pressure $=1 \mathrm{MPa}(1)$, $2 \mathrm{MPa}(2), 3 \mathrm{MPa}(3)$, and $4 \mathrm{MPa}$ (4)

** \pm determination uncertainty

\begin{tabular}{llllllll}
\hline Run & \multicolumn{6}{l}{ Experimental conditions* } \\
\cline { 2 - 7 } & Repetition & $\mathrm{pH}$ & $\mathrm{K}_{2} \mathrm{FeO}_{4}$ & Time & Temperature & Pressure & $\mathrm{COD}, \mathrm{mg} \mathrm{O}_{2} / \mathrm{L}^{* *}$ \\
\hline 46 & 3 & 4 & 2 & 3 & 1 & 4 & $410 \pm 60$ \\
47 & 3 & 4 & 3 & 2 & 4 & 1 & $240 \pm 40$ \\
48 & 3 & 4 & 4 & 1 & 3 & 2 & $220 \pm 30$ \\
\hline
\end{tabular}

presence of heavy metals may affect the effectiveness of treatment by AOPs (Andreozzi et al., 1999).

The effect of various combinations of experimental conditions on COD of landfill leachate after the treatment is presented in Table 2. The investigated conditions were $\mathrm{pH}$, concentration of $\mathrm{K}_{2} \mathrm{FeO}_{4}$, reaction time, temperature, and pressure. The lowest COD after the treatment, $150 \mathrm{mg} \mathrm{O} / \mathrm{L}$, was obtained for combination 8, 24, and 40, whereas the highest COD was observed for combination 1, 17, and 33 ( 730 , 705 , and $695 \mathrm{mg} \mathrm{O}_{2} / \mathrm{L}$, respectively). In combinations 8, 24, and 40, the highest dose of $2.0 \mathrm{~g} / \mathrm{L} \mathrm{K}_{2} \mathrm{FeO}_{4}$ has been applied at $\mathrm{pH} 3.5,30{ }^{\circ} \mathrm{C}$ temperature, and $1 \mathrm{MPa}$ pressure. The reaction time was $45 \mathrm{~min}$. At these conditions, COD decreased by $92.0 \%$, from 1880 to $150 \mathrm{mg} \mathrm{O}_{2} / \mathrm{L}$. It indicates that concentration of $\mathrm{K}_{2} \mathrm{FeO}_{4}$ and reaction time were the most influential parameters, and process is slightly affected by variation of temperature and pressure. In the case of combinations 1,17 , and 33, the lowest experimental conditions have been applied: $\mathrm{pH} 2.5,0.5 \mathrm{~g} / \mathrm{L} \mathrm{K}_{2} \mathrm{FeO}_{4}$, $20{ }^{\circ} \mathrm{C}$, and $1 \mathrm{MPa}$. The reaction time was $15 \mathrm{~min}$. At these conditions, a decrease of COD value by 61.2 , 62.5 , and $63.0 \%$ was observed (from 1880 to 730 , 705 , and $695 \mathrm{mg} \mathrm{O}_{2} / \mathrm{L}$, respectively). The triplicate repetition of the experiments at lower and higher experimental conditions indicated that the treatment process is very reproducible and repeatable with very 
low variability in output. In other words, the variability of the experimental results and experimental bias is very small at all combination of experimental conditions.

The analysis of variance (ANOVA) is frequently used in quantitative assessment whether there is a statistical association between experimental parameters and process outputs (Hsieh et al., 2009; Thomas et al., 2018, 2020). In this study, ANOVA was used to determine the significance of each parameter influence on the output of investigated process - a decrease of COD after the treatment. The variance ratio (F-ratio) was used to assess the significance of the parameter. The ANOVA results are presented in Table 3.

The results of ANOVA confirmed that experimental bias is statistically insignificant, and process output is repeatable and reproducible at the same experimental conditions. However, $\mathrm{pH}, \mathrm{K}_{2} \mathrm{FeO}_{4}$ dose, reaction time, and temperature were the most statistically significant parameters $(p<0.05)$. The results are in accordance with earlier studies. Lan et al. (2014) and Thomas et al. (2020) also indicated that $\mathrm{pH}$ value, concentration of $\mathrm{K}_{2} \mathrm{FeO}_{4}$, and reaction time were statistically significant parameters for optimization of the treatment process. Additionally, Zhang et al. (2014) also indicated that temperature is important parameter for optimization of potassium ferrate(VI) treatments.

In Taguchi's method, notion of "Signal to Noise Ratio" (S/N ratio) is used that measure the contribution of each parameter to process output variability. The optimization procedure based on two steps: highly fractional factorial experiments (orthogonal array designs) at various levels of process' parameters (Tab. 1) and using the data to select those levels maximized S/N ratio (Cheng et al., 2010; Chowdhury et al., 2014; Thomas et al., 2018; Więckol-Ryk et al., 2020). Optimal experimental conditions and corresponding S/N ratio are presented in Table 4.

Application orthogonal array designs in TM allow to select independent parameters that do not interrelate with each other (Asghar et al., 2014; Srinu \& Pydi, 2001; Thomas et al., 2018, 2020). Significance of the effects illustrates which experimental parameters are the most affecting. The process is governed (Tab. 4) by the $\mathrm{K}_{2} \mathrm{FeO}_{4}$ dose (4.6421) and $\mathrm{pH}$ (1.2063). The contribution of reaction time (0.5809), air pressure (0.3064), and temperature (0.1929) is significantly smaller. A graphical presentation of the
$\eta=S / N$ for each level of the parameters is shown in the Fig. 2. The combination pH 3.5 (level 2), $2.0 \mathrm{~g} / \mathrm{L}$ $\mathrm{K}_{2} \mathrm{FeO}_{4}$ (level 4), duration time 45 min (level 3), temperature $30{ }^{\circ} \mathrm{C}$ (level 2), and pressure $1 \mathrm{MPa}$ (level 1) gave the highest $\mathrm{S} / \mathrm{N}$ ratio -43.3819 .

A wide range of $\eta$ value suggests that the $\mathrm{pH}$ value and the $\mathrm{K}_{2} \mathrm{FeO}_{4}$ dose are considerably the most influential in comparison to other parameters. A very small range of $\eta$ value for repetition parameter indicates that experimental bias related to conducting of the experiments is not significant. The ascending line for $\mathrm{K}_{2} \mathrm{FeO}_{4}$ dose shows that the efficiency of the process increases with dose. In the case of $\mathrm{pH}$ value, the shape of the line indicates that there is a certain optimum at which the process output reaches its maximum value. The same applied to time. Extension of the process duration (more than $45 \mathrm{~min}$ ) and increasing the pressure value (more than $1 \mathrm{MPa}$ ) did not bring improvement in decreasing of COD. Thus, the optimal conditions were as follows: $\mathrm{pH} 3.5, \mathrm{~K}_{2} \mathrm{FeO}_{4}$ $2.0 \mathrm{~g} / \mathrm{L}$, time $45 \mathrm{~min}$, temperature $30{ }^{\circ} \mathrm{C}$, pressure $1 \mathrm{MPa}$.

At optimal conditions, after additional flocculation with $0.2 \mathrm{~mL}$ of $0.05 \mathrm{wt} . \%$ anionic flocculant, the color of the effluent was reduced by $97.1 \%$ whereas the COD, TOC, and TN were reduced by $91.5 \%$, $91.1 \%$, and $48.2 \%$, respectively (Tab. 5). Additionally, at the optimal condition, the COD of the treated effluent $160 \pm 20 \mathrm{mg} \mathrm{O}_{2} / \mathrm{L}$ was similar to the COD $150 \pm 20 \mathrm{mg} \mathrm{O}_{2} / \mathrm{L}$ after treatment at combination of experimental condition 8, 24, and 40 (Table 1). For comparison, the treatment of the landfill leachate was

Table 3 The results of ANOVA

\begin{tabular}{|c|c|c|c|c|c|}
\hline \multirow[t]{2}{*}{ Effect/factor } & \multicolumn{5}{|c|}{$\begin{array}{l}\text { Analysis of variance, } \text { mean }=-50.450, \\
\text { sigma }=4.26646\end{array}$} \\
\hline & SS & df & MS & $\mathrm{F}$ & $p$ \\
\hline Repetition & 0.4864 & 2 & 0.2432 & 3.013 & 0.0642 \\
\hline $\mathrm{pH}$ & 25.1881 & 3 & 8.3960 & 104.007 & $<<0.05$ \\
\hline $\mathrm{K}_{2} \mathrm{FeO}_{4}$ dose & 811.1091 & 3 & 270.3697 & 3349.251 & $<<0.05$ \\
\hline $\begin{array}{l}\text { Reaction } \\
\text { time }\end{array}$ & 13.5359 & 3 & 4.5120 & 55.893 & $<<0.05$ \\
\hline Temperature & 0.8030 & 3 & 0.2677 & 3.316 & 0.0331 \\
\hline Pressure & 1.9807 & 3 & 0.6602 & 8.179 & 0.0004 \\
\hline Residual & 2.5264 & 30 & 0.0842 & - & - \\
\hline
\end{tabular}

$S S$ predicted residual error sum of squares, $M S$ mean square error, $F$ statistics, $d f$ number of degrees of freedom 
Table $4 \mathrm{~S} / \mathrm{N}$ ratio in optimal experimental conditions

\begin{tabular}{llrl}
\hline Effect/factor & \multicolumn{2}{l}{$\begin{array}{l}\text { Predicted S/N ratio under optimal conditions, } \\
\text { mean }=-50.438, \text { sigma }=4.27668\end{array}$} \\
\cline { 2 - 4 } & $\begin{array}{l}\text { Parameter } \\
\text { value }\end{array}$ & $\begin{array}{l}\text { Significance } \\
\text { of the effect }\end{array}$ & Standard error \\
\hline Repetition & 3 & 0.1399 & 0.0710 \\
$\mathrm{pH}$ & $2($ for & 1.2063 & 0.0820 \\
& $\mathrm{pH}=3.5)$ & & \\
$\mathrm{K}_{2} \mathrm{FeO}_{4}$ & $4($ for $2.0 \mathrm{~g} / \mathrm{L})$ & 4.6421 & 0.0820 \\
Time $_{\text {Temperature }}$ & $3($ for $45 \mathrm{~min})$ & 0.5809 & 0.0820 \\
Pressure & $2\left(\right.$ for $\left.30{ }^{\circ} \mathrm{C}\right)$ & 0.1929 & 0.0820 \\
Expected S/N & $1($ for $1 \mathrm{MPa})$ & 0.3064 & 0.0820 \\
value & - & -43.3819 & - \\
\hline
\end{tabular}

conducting at the same conditions but lower temperature $19 \pm 1^{\circ} \mathrm{C}$ and atmospheric pressure $0.1013 \mathrm{MPa}$, At these conditions, the obtained reduction of color, COD, TOC, and TN was 99.9\%, 83.0\%, 79.0\%, and $19.1 \%$, respectively (Tab. 5). The results suggest that the use of a combined coagulation and oxidation process at elevated pressure and temperature is more effective than the process conducted at ambient conditions. The efficiency of TP removal at condition cases was the same and reached $100 \%$. The highest efficiency of color reduction and heavy metal removal of leachate was obtained at ambient conditions. The decreased efficiency of metal removal after oxidation at elevated conditions (64.0 - 100\%) was likely correlated with an increase of color after the process. At these conditions, an increased color of the leachate was also observed after the flocculation process. This can be explained by formation of colorful metal complexes with degradation products, or small particles of insoluble salts.

It seems that decreasing of landfill leachate's $\mathrm{pH}$ from $7.9 \pm 0.1$ to 3.5 only slightly increase the cost of proposed treatment and consumption of chemicals. However, the application of $\mathrm{K}_{2} \mathrm{FeO}_{4}$ is more effective in acidic than in neutral and alkaline environment (Eqs. 2 and 3). The redox potential is higher in an acidic than in an alkaline environment $\left(\mathrm{E}^{0}=2.2 \mathrm{~V}\right.$ and $\mathrm{E}^{0}=0.7 \mathrm{~V}$, respectively)

$$
\begin{aligned}
& \mathrm{FeO}_{4}{ }^{2-}+8 \mathrm{H}^{+}+3 \mathrm{e}^{-} \leftrightarrows \mathrm{Fe}^{3+}+4 \mathrm{H}_{2} \mathrm{O} \\
& \mathrm{FeO}_{4}{ }^{2-}+8 \mathrm{H}_{2} \mathrm{O}+3 \mathrm{e}^{-} \leftrightarrows \mathrm{Fe}(\mathrm{OH})_{3} \downarrow+8 \mathrm{H}_{2} \mathrm{O}
\end{aligned}
$$

Additionally, at acidic conditions, carboxylic acids, the main process by-products, are in less soluble in protonated. Other carboxylic acids may also formed insoluble salt with $\mathrm{Fe}^{3+}$. Potassium ferrate(VI) is stable in alkaline condition ( $\mathrm{Li}$ et al., 2005). However, at strong alkaline conditions, above
Fig. 2 ETA $(\eta)$ values versus input parameter values plot for landfill leachate $\left(\mathrm{pH}_{1}=2.5, \mathrm{pH}_{2}=3.5\right.$, $\mathrm{pH}_{3}=4.5, \mathrm{pH}_{4}=5.5$, $\mathrm{K}_{2} \mathrm{FeO}_{4(1)}=0.5 \mathrm{~g} / \mathrm{L}$, $\mathrm{K}_{2} \mathrm{FeO}_{4(2)}=1.0 \mathrm{~g} / \mathrm{L}$, $\mathrm{K}_{2} \mathrm{FeO}_{4(3)}=1.5 \mathrm{~g} / \mathrm{L}$, $\mathrm{K}_{2} \mathrm{FeO}_{4(4)}=2.0 \mathrm{~g} / \mathrm{L}$, Time $_{(1)}=15 \mathrm{~min}$, Time $_{(2)}=30 \mathrm{~min}$, Time $_{(3)}=45 \mathrm{~min}$, Time $_{(4)}=60 \mathrm{~min}$, Temperature $_{(1)}=20^{\circ} \mathrm{C}$, Temperature $_{(2)}=30^{\circ} \mathrm{C}$, Temperature $_{(3)}=40^{\circ} \mathrm{C}$, Temperature $_{(4)}=50^{\circ} \mathrm{C}$, Pressure $_{(1)}=1 \mathrm{MPa}$, Pressure $_{(2)}=2 \mathrm{MPa}$, Pressure $_{(3)}=3 \mathrm{MPa}$, Pressure $_{(4)}=4 \mathrm{MPa}$ ). The black horizontal lines represent \pm standard value

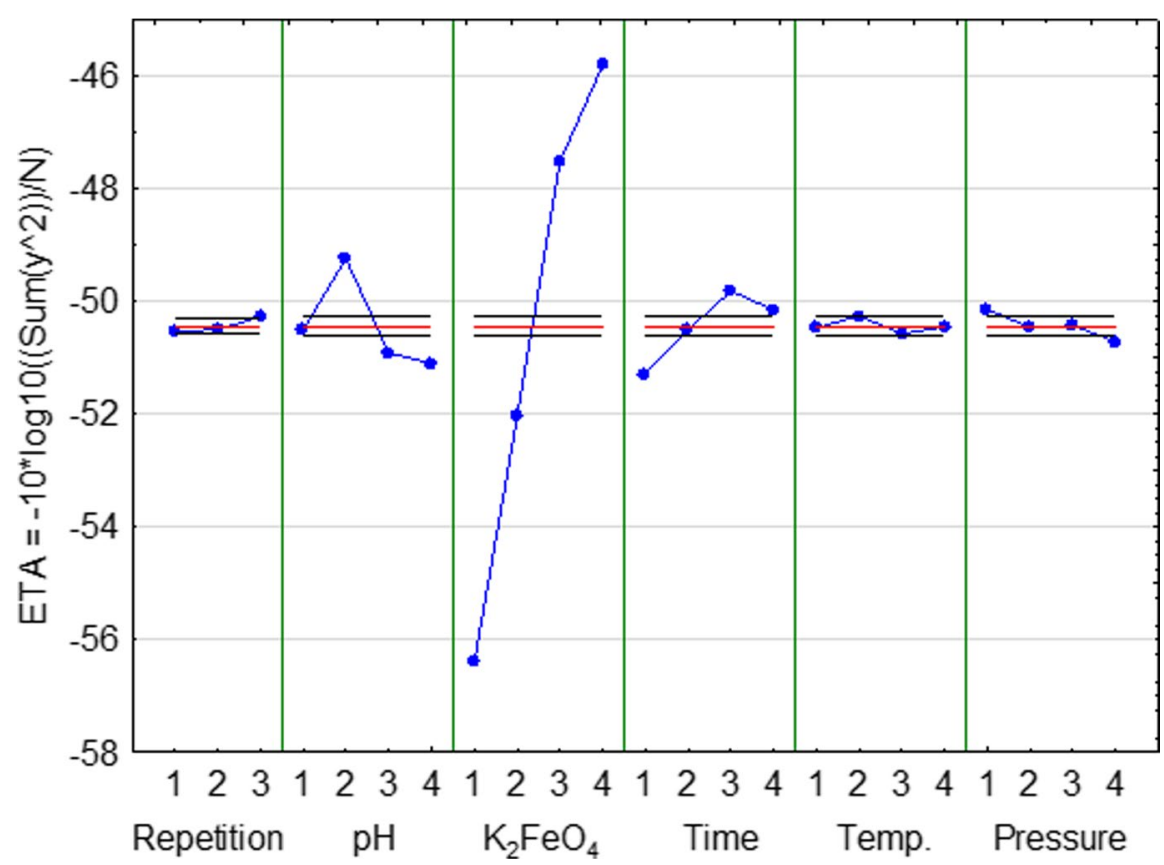


Table 5 The selected physicochemical parameters of raw and treated leachates

\begin{tabular}{|c|c|c|c|c|c|c|}
\hline Parameter* & Unit & $\begin{array}{l}\text { Leachate } \\
\text { before treat- } \\
\text { ment }\end{array}$ & $\begin{array}{l}\text { Leachate after treat- } \\
\text { ment }(\mathrm{pH}=3.5, \\
\mathrm{K}_{2} \mathrm{FeO}_{4}=2.0 \mathrm{~g} / \mathrm{L}, \\
\text { time }=45 \mathrm{~min} \text {, tem- } \\
\text { perature } 30^{\circ} \mathrm{C} \text {, pressure } \\
1 \mathrm{MPa})\end{array}$ & Effect, $\% * *$ & $\begin{array}{l}\text { Leachate after treat- } \\
\text { ment, } \mathrm{pH}=3.5, \\
\mathrm{~K}_{2} \mathrm{FeO}_{4}=2.0 \mathrm{~g} / \mathrm{L}, \\
\text { Time }=45 \mathrm{~min} \text {, Tem- } \\
\text { perature } 19^{\circ} \mathrm{C} \text {, Pressure } \\
0.1013 \mathrm{MPa}\end{array}$ & Effect, \%** \\
\hline $\mathrm{pH}$ & - & $7.9 \pm 0.1$ & $9.5 \pm 0.1$ & - & $9.5 \pm 0.1$ & - \\
\hline $\begin{array}{l}\text { Color after filtering } \\
\text { through the } 0.45 \mu \mathrm{m} \\
\text { syringe filter }\end{array}$ & $\mathrm{mg} \mathrm{Pt} / \mathrm{L}$ & $1550 \pm 310$ & $45 \pm 9 \mathrm{mg} / \mathrm{L}$ & $97.1 \downarrow$ & $2.0 \pm 0.4$ & $99.9 \downarrow$ \\
\hline $\begin{array}{l}\text { Chemical oxygen } \\
\text { demand, COD }\end{array}$ & $\mathrm{mg} \mathrm{O}_{2} / \mathrm{L}$ & $1880 \pm 280$ & $160 \pm 20$ & $91.5 \downarrow$ & $320 \pm 50$ & $83.0 \downarrow$ \\
\hline $\begin{array}{l}\text { Total organic carbon, } \\
\text { TOC }\end{array}$ & $\mathrm{mg} / \mathrm{L}$ & $620 \pm 90$ & $55 \pm 8$ & $91.1 \downarrow$ & $130 \pm 20$ & $79.0 \downarrow$ \\
\hline Total nitrogen $(\mathrm{TN})$ & $\mathrm{mg} / \mathrm{L}$ & $220 \pm 30$ & $114 \pm 17$ & $48.2 \downarrow$ & $178 \pm 25$ & $19.1 \downarrow$ \\
\hline Total phosphorus (TP) & $\mathrm{mg} / \mathrm{L}$ & $6.0 \pm 0.9$ & Not detected, $<0.3$ & $100.0 \downarrow$ & Not detected, $<0.3$ & $100.0 \downarrow$ \\
\hline \multicolumn{7}{|c|}{ Heavy metals removal $* * *$} \\
\hline Cadmium & $\mathrm{mg} / \mathrm{L}$ & $0.020 \pm 0.004$ & $<0.01$ & $100.0 \downarrow$ & $<0.01$ & $100.0 \downarrow$ \\
\hline Chromium (total) & $\mathrm{mg} / \mathrm{L}$ & $0.10 \pm 0.02$ & $0.05 \pm 0.01$ & $50.0 \downarrow$ & $<0.01$ & $100.0 \downarrow$ \\
\hline Copper & $\mathrm{mg} / \mathrm{L}$ & $0.50 \pm 0.05$ & $0.09 \pm 0.02$ & $82.0 \downarrow$ & $0.009 \pm 0,002$ & $98.2 \downarrow$ \\
\hline Iron & $\mathrm{mg} / \mathrm{L}$ & $38.0 \pm 3.8$ & $2.20 \pm 0.4$ & $94.2 \downarrow$ & $0,28 \pm 0.06$ & $99.3 \downarrow$ \\
\hline Nickel & $\mathrm{mg} / \mathrm{L}$ & $0.12 \pm 0.02$ & $0.04 \pm 0.01$ & $66.7 \downarrow$ & $<0.01$ & $100.0 \downarrow$ \\
\hline Lead & $\mathrm{mg} / \mathrm{L}$ & $0.25 \pm 0.05$ & $0.09 \pm 0.02$ & $64.0 \downarrow$ & $<0.01$ & $100.0 \downarrow$ \\
\hline Zinc & $\mathrm{mg} / \mathrm{L}$ & $14.0 \pm 1.4$ & $1.5 \pm 0.3$ & $89.3 \downarrow$ & $<0.01$ & $100.0 \downarrow$ \\
\hline
\end{tabular}

*Parameter value \pm the measurement uncertainty for an extension factor $\mathrm{k}=2$

*** Wastewater treatment efficiency $=\frac{(C 1-C 2) \times 100 \%}{\mathrm{Cl}}$, where $\mathrm{c}_{1}$ is the concentration in the raw landfill leachate, $\mathrm{c}_{2}$ is the concentration in the treated landfill leachate; does not apply to $\mathrm{pH}$

${ }^{* * * *}$ The lower quantification limit of heavy metals was $0.01 \mathrm{mg} / \mathrm{L}$, except $\mathrm{Cu} 0.005 \mathrm{mg} / \mathrm{L}$

$\mathrm{pH} 10, \mathrm{Fe}(\mathrm{OH})_{3}$ is partially hydrolyzed (Graham et al., 2004; Sharma et al., 2000) and the removal of organic compounds and partially heavy metals by iron hydroxide flocs may be reduced. Lv et al. (2018) have shown that at $\mathrm{pH} 6.5$ and 7.5, a lower iron doses were needed for $\mathrm{FeO}_{4}{ }^{2-}$ coagulation than for direct $\mathrm{Fe}^{3+}$ coagulation. Moreover, the results of previous studies suggested that the reaction of potassium ferrate(VI) with organic compounds could be faster than self-decomposition reaction in acidic conditions (Moradnia et al., 2016; Thomas \& Zdebik, 2019; Thomas et al., 2020). It can be explained by formation of various complexes of $\mathrm{FeO}_{4}{ }^{2-}$ with organic matter and presence of carbonate that increase the stability of potassium ferrate(VI) in acidic solution (Luo et al., 2019). Addition of sulfuric acid for $\mathrm{pH}$ adjustment removes also scale-forming magnesium and calcium and decreases solubility of macromolecular carboxylic acid due to protonation. The formation of peroxyl radicals is involved mechanism of organic compound oxidation by $\mathrm{K}_{2} \mathrm{FeO}_{4}$ (Drzewicz et al, 2019). According to Kim et al. (2000), the amount of oxygen needed for oxidation organic compounds is calculated according to following equation:

$$
\begin{aligned}
\mathrm{C}_{n} \mathrm{H}_{m} \mathrm{O}_{e} \mathrm{X}_{k} \mathrm{~N}_{j} \mathrm{~S}_{i} \mathrm{P}_{h}+b \mathrm{O}_{2} \rightarrow n \mathrm{CO}_{2} & +\left(\frac{m-k-3 j-2 i-3 h}{2}\right) \mathrm{H}_{2} \mathrm{O} \\
& +k \mathrm{HX}+j \mathrm{NH}_{3}+i \mathrm{H}_{2} \mathrm{SO}_{4}+h \mathrm{H}_{3} \mathrm{PO}_{4}
\end{aligned}
$$

where $X$ represents the sum of all halogens and $b=n+\frac{m-k-3 j-2 i-3 h}{4}-\frac{e}{2}+2 i+2 h$.

Thus, such large amount of oxygen for oxidation of organic compounds in leachate cannot be delivered with ferrate anion. Moreover, solubility of oxygen in landfill leachate is very low due to high salinity and organic content. In such conditions, the high concentration of oxygen in solution can 
be achieved only by application of high pressure. Thus, increasing the pressure improves performance of the process. However, it needs further studies to confirm this. Ferrates are well-known coagulationflocculation agent (Lv et al., 2018). Part of organic compounds is removed from the solution with iron hydroxide flocs that is formed during the oxidation process. However, $\mathrm{Fe}$ (III) may be reduced to $\mathrm{Fe}$ (II) by organic compounds (Zhou et al., 2021). Thus, effectiveness of potassium ferrate(VI)-induced coagulation and flocculation may be reduced at elevated temperature and pressure. On the other hand, in Fenton reaction, $\mathrm{Fe}$ (II) reacts with $\mathrm{H}_{2} \mathrm{O}_{2}$ to form highly reactive hydroxyl radicals. Hydrogen peroxide may be formed during termination of peroxyl radical during oxidation by potassium ferrate(VI). However, the elucidation of the multistep process mechanism of potassium ferrate(VI) oxidation at elevated temperature and pressure needs further studies.

Ferrate(VI) salts are unstable in both solid form and in the water solutions. However, the oxidant may be generated in situ by electrochemical processes (Jiang et al., 2009). According to Diaz et al (2021), the highest efficiency of ferrate(VI) generation was achieved using gray cast iron (GCI), in presence of $10 \mathrm{~mol} / \mathrm{L} \mathrm{NaOH}$. The production rate was $0.979 \mathrm{~mol} \mathrm{FeO}_{4} \mathrm{~m}^{-3}$ day $^{-1}$ (including time for cleaning in between cycles) at the energy consumption $8 \mathrm{kWh} \mathrm{kg}^{-1}$. GCI is widely available commercially material at a low cost, which is simple to shape into different electrode structures. It does not contained toxic metal like chromium. Comparatively, production of chlorine via electrolysis of $\mathrm{NaCl}$ has a typical energy consumption of 2.2-2.6 kWh kg-1 $\mathrm{Cl}_{2}$ whereas electrogeneration of ozone (depends on solution and electrode material composition) has energy consumption in the range from $\sim 18$ to $175 \mathrm{kWh} \mathrm{kg}^{-1} \mathrm{O}_{3}$ (Diaz et al (2021). However, $\mathrm{Cl}_{2}$ and ozone have lower oxidation potential and lower reactivity than potassium ferrate(VI). As results, $\mathrm{Cl}_{2}$ and $\mathrm{O}_{3}$ require longer contact times which decrease effectiveness of the process.

In summary, increasing temperature and pressure is a viable option to improve effectiveness of landfill leachate treatment by potassium ferrate(VI). Solubility of oxygen needed in the process increases with a pressure increase whereas reactivity of the compounds increases with temperature. Additionally, microwave irradiation applied in this process will increase efficiency of heat energy transfer to the solution and effectively break molecular bonds in organic compounds (Andreozzi et al., 1999; Serpone et al., 2010). However, further research at real scale is needed.

\section{Conclusions}

The impact of pressure and temperature on the effectiveness of landfill leachate treatment by potassium ferrate(VI) was investigated. The Taguchi's method of experiment design has been used in optimization of the process. Based on this method, it has been shown that the most influential parameters on the treatment process output were the following parameters: $\mathrm{pH}, \mathrm{K}_{2} \mathrm{FeO}_{4}$ dose, reaction time, temperature, and pressure. Application of TM significantly reduced the number of experiments needed for determination of optimum conditions. The determined optimum conditions were as follows:

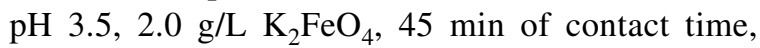
$30{ }^{\circ} \mathrm{C}, 1 \mathrm{MPa}$. At optimal condition, a decrease of color by $97.1 \%$, COD by $91.5 \%$, TOC by $91.1 \%$, TN by $48.2 \%$, and TP by $100 \%$ was obtained. Comparatively, at the same condition, but lower the atmospheric pressure $(0.1013 \mathrm{MPa})$ and temperature $19{ }^{\circ} \mathrm{C}$, a decrease of color by $99.9 \%$, COD by $83.0 \%$, TOC by $79.0 \%$, TN by $19.1 \%$, and TP by $100 \%$ was obtained. Application of elevated temperature and pressure is a viable option to improve effectiveness of landfill leachate treatment by potassium ferrate(VI). However, it needs further research at real-scale applications.

Author Contribution Conceptualization, M.T.; methodology, M.T.; statistical analysis, M.T., A.W.-R., B.P.; formal analysis, M.T., P.D., A.W.-R.; data curation, M.T., P.D., A.W.R., B.P.; writing - original draft preparation, M.T.; writingreview and editing, M.T., P.D.; visualization, M.T., B.P.; supervision, P.D.; project administration, not applicable; funding acquisition, not applicable. All authors have read and agreed to the published version of the manuscript.

Data Availability The datasets obtained during this study are available from the corresponding author on reasonable request.

\section{Declarations}


Ethics Approval and Consent to Participate Not applicable.

Consent for Publication Not applicable.

Competing Interests The authors declare no competing interests.

Open Access This article is licensed under a Creative Commons Attribution 4.0 International License, which permits use, sharing, adaptation, distribution and reproduction in any medium or format, as long as you give appropriate credit to the original author(s) and the source, provide a link to the Creative Commons licence, and indicate if changes were made. The images or other third party material in this article are included in the article's Creative Commons licence, unless indicated otherwise in a credit line to the material. If material is not included in the article's Creative Commons licence and your intended use is not permitted by statutory regulation or exceeds the permitted use, you will need to obtain permission directly from the copyright holder. To view a copy of this licence, visit http://creativecommons.org/licenses/by/4.0/.

\section{References}

Abbas, A. A., Jingsong, G., Ping, L. Z., Ya, P. Y., \& AlRekabi, W. S. (2009). Review on landfill leachate treatments. American Journal of Applied Sciences, 6(4), 672-684. https://doi.org/10.3844/ajassp.2009.672.684

Adar, E., Ince, M., \& Bilgili, M. S. (2019). Evaluation of development in supercritical water oxidation technology. Desalination and Water Treatment, 161, 243-253. https://doi.org/10.5004/dwt.2019.24297

Akiya, N., \& Savage, P. E. (2002). Roles of water for chemical reactions in high-temperature water. Chemical Reviews, 102(8), 2725-2750. https://doi.org/10.1021/ cr000668w

Anglada, Á., Urtiaga, A., Ortiz, I., Mantzavinos, D., \& Diamadopoulos, E. (2011). Treatment of municipal landfill leachate by catalytic wet air oxidation: Assessment of the role of operating parameters by factorial design. Waste Management, 31(8), 1833-1840. https://doi.org/ 10.1016/j.wasman.2011.03.023

Andreozzi, R., Caprio, V., Insola, A., \& Martota, R. (1999). Advanced oxidation processes (AOP) for water purification and recovery. Catalysis Today, 53, 51-59. https:// doi.org/10.1016/S0920-5861(99)00102-9

Asghar, A., Raman, A. A. A., \& Daud, W. M. A. W. (2014). A comparison of central composite design and Taguchi method for optimizing Fenton process. The Scientific World Journal, 869120, 1-14. https://doi.org/10.1155/ 2014/869120

Aziz, S. Q. (2012). Landfill leachate treatment using powdered activated carbon augmented sequencing batch reactor (SBR) process. PhD Thesis, School of Civil Engineering, University Sains Malaysia, Malaysia.

Carpenter, J., Badve, M., Rajoriya, S., George, S., Saharan, V. K., \& Pandit, A. B. (2017). Hydrodynamic cavitation:
An emerging technology for the intensification of various chemical and physical processes in a chemical process industry. Reviews in Chemical Engineering, 33(5), 433-468. https://doi.org/10.1515/revce-2016-0032

Chen, G., Lam, W. W. Y., Lo, P.-K., Man, W.-L., Chen, L., Lau, K.-C., \& Lau, T.-C. (2018). Mechanism of water oxidation by ferrate(VI) at pH 7-9. Chemistry - A European Journal, 24, 18735. https://doi.org/10.1002/chem. 201803757

Cheng, C., Yao, K. S., Hsieh, Y. H., Hsieh, L. L., \& Chang, C. Y. (2010). Optimizing preparation of the $\mathrm{TiO}_{2}$ thin film reactor using the Taguchi method. Materials \& Design, 31(4), 1749-1751. https://doi.org/10.1016/j. matdes.2009.07.055

Chowdhury, A., Chakraborty, R., Mitra, D., \& Biswas, D. (2014). Optimization of the production parameters of octyl ester biol-lubricant using Taguchi's design method and physicochemical characterization of the product. Industrial Crops and Products, 52, 783-789. https://doi. org/10.1016/j.indcrop.2013.11.007

Diaz, M., Doederer, K., Keller, J., Cataldo, M., Donose, B.-C., Ali, Y., \& Ledezma, P. (2021). Towards in situ electrogeneration of ferrate for drinking water treatment: A comparison of three low-cost sacrificial iron electrodes. Journal of Electroanalytical Chemistry, 880, 114897.

Drzewicz, P., Drobniewska, A., Sikorska, K., \& NałęczJawecki, G. (2019). Analytical and ecotoxicological studies on degradation of fluoxetine and fluvoxamine by potassium ferrate. Environmental Technology, 40(25), 3265-3275. https://doi.org/10.1080/09593330.2018. 1468488

Drzewicz, P., Nałęcz-Jawecki, G., Gryz, M., Sawicki, J., Bojanowska-Czajka, A., Głuszewski, W., Kulisa, K., Wołkowicz, S., \& Trojanowicz, M. (2004). Monitoring of toxicity during degradation of selected pesticides using ionizing radiation. Chemosphere, 57, 135-145. https://doi. org/10.1016/j.chemosphere.2004.05.019

Drzewicz, P., Perez-Estrada, L., Alpatova, A., Martin, J. W., \& Gamal El-Din, M. (2012). Impact of peroxydisulfate in the presence of zero valent iron on the oxidation of cyclohexanoic acid and naphthenic acids from oil sands process-affected water. Environmental Science and Technology, 46(16), 8984-8991. https://doi.org/10.1021/es301 1546

Drzewicz, P., Pańta, P., Gluszewski, W., \& Trojanowicz, M. (1999). Effect of selected scavengers on radiolytic degradation of 2,4-dichlorophenol for environmental purposes. Journal of Radioanalytical Nuclear Chemistry, 242, 601609. https://doi.org/10.1007/BF02347368

Ferreira Pinto, L., Feihrmann, A. C., Tavares, C. R. G., dos Reis Coimbra, J. S., Saldaña, M. D. A., Vedoy, D. R. L., \& Cardozo-Filho, L. (2017). Leachate treatment using supercritical water. The Canadian Journal of Chemical Engineering, 95, 1442-1448. https://doi.org/10.1002/cjce. 22818

Gautam, P., Kumar, S., \& Lokhandwala, S. (2019). Advanced oxidation processes for treatment of leachate from hazardous waste landfill: A critical review. Journal of Cleaner Production, 237, 117639. https://doi.org/10.1016/j.jclep ro.2019.117639 
Graham, N., Jiang, C. C., Li, X. Z., Jiang, J. Q., \& Ma, J. (2004). The influence of $\mathrm{pH}$ on the degradation of phenol and chlorophenols by potassium ferrate. Chemosphere, 56, 949-956. https://doi.org/10.1016/j.chemosphere.2004. 04.060

Hayyan, M., Hashim, M. A., \& Al Nashef, I. M. (2016). Superoxide ion: Generation and chemical implications. Chemical Reviews, 116, 3029-3085. https://doi.org/10.1021/acs. chemrev.5b00407

Hsieh, L., Kang, H., Shyu, H., \& Chang, C. (2009). Optimal degradation of dye wastewater by ultrasound/Fenton method in the presence of nanoscale iron. Water Science and Technology, 60(5), 1295-1301. https://doi.org/10. 2166/wst.2009.366

ISO 10523:2008 Water quality. Determination of $\mathrm{pH}$.

ISO 15705:2002 Water quality. Determination of the chemical oxygen demand index (ST-COD). Small-scale sealed-tube method.

ISO 9297:1994 Water quality. Determination of chloride. Silver nitrate titration with chromate indicator (Mohrs's method).

ISO 9280:2002 Water quality. Determination of sulfate. Gravimetric method using barium chloride.

ISO 11885:2007 Water quality-determination of selected elements by inductively coupled plasma optical emission spectrometry.

Jiang, J.-Q., Stanford, C., \& Alsheyab, M. (2009). The online generation and application of ferrate(VI) for sewage treatment-a pilot scale trial. Separation and Purification Technology, 68, 227-231.

Jankowska, A., Biesaga, M., Drzewicz, P., Trojanowicz, M., \& Pyrzyńska, K. (2004). Chromatographic separation of chlorophenoxy acid herbicides and their radiolytic degradation products in water samples. Water Research, 38, 3259-3264. https://doi.org/10.1016/j.watres.2004.03. 032

Jing, G., Luan, M., \& Chen, T. (2016). Progress of catalytic wet air oxidation technology. Arabian Journal of Chemistry, 9, S1208-S1213. https://doi.org/10.1016/j.arabjc. 2012.01.001

Keav, S., Barbier, J., \& Duprez, D. (2011). Deactivation and regeneration of wet air oxidation catalysts. Catalysis Science \& Technology, 1, 342-353. https://doi.org/10.1039/ C0CY00085J

Keyikoglu, R., Karatas, O., Rezania, H., Kobya, M., Vatanpour, V., \& Khataee, A. (2021). A review on treatment of membrane concentrates generated from landfill leachate treatment processes. Separation and Purification Technology, 259, 118182. https://doi.org/10.1016/j.seppur.2020. 118182

Kim, Y.-C., Sasaki, S., Yano, K., Ikebukuro, K., Hashimoto, K., \& Karube, I. (2000). Relationship between theoretical and oxygen demand and photocatalytic chemical oxygen demand for specific classes of organic chemicals. The Analyst, 125, 1915-1918. https://doi.org/10.1039/B0070 $05 \mathrm{~J}$

Kirmizakis, P., Tsamoutsoglou, C., Kayan, B., \& Kalderis, D. (2014). Subcritical water treatment of landfill leachate: Application of response surface methodology. Journal of
Environmental Management, 146, 9-15. https://doi.org/ 10.1016/j.jenvman.2014.04.037

Kolaczkowski, S. T., Plucinski, P., Beltran, F. J., Rivas, F. J., \& McLurgh, D. B. (1999). Wet air oxidation: A review of process technologies and aspects in reactor design. Chemical Engineering Journal, 73(2), 143-160. https://doi.org/ 10.1016/S1385-8947(99)00022-4

Kruse, A., \& Dinjus, E. (2007). Hot compressed water as reaction medium and reactant: Properties and synthesis reaction. Journal of Supercritical Fluids, 39, 362-380. https:// doi.org/10.1016/j.supflu.2006.03.016

Kulikowska, D., \& Klimiuk, E. (2008). The effect of landfill age on municipal leachate composition. Bioresources Technology, 99, 5981-5985.

Lan, S., Liu, X., Chen, R., Wan, Y., Wu, X., \& Zhang, H. (2014). Study on pretreatment of landfill leachate by potassium ferrate. Desalination and Water Treatment, 52, 2757-2764. https://doi.org/10.1080/19443994.2013. 807063

Li, C., Li, X. Z., \& Graham, N. (2005). A study of the preparation and reactivity of potassium ferrate. Chemosphere, 61(4), 537-543. https://doi.org/10.1016/j.chemosphere. 2005.02.027

Locke, B. R., Sato, M., Sunka, P., Hoffmann, M. R., \& Chang, J.-S. (2006). Electrohydraulic discharge and nonthermal plasma for water treatment. Industrial \& Engineering Chemistry Research, 45, 882-905. https://doi.org/10. 1021/ie050981u

Luo, C., Feng, M., Sharma, V. K., \& Huang, C.-H. (2019). Oxidation of pharmaceuticals by ferrate(VI) in hydrolyzed urine: Effects of major inorganic constituents. Environmental Science \& Technology, 53, 5272-5281. https://doi.org/10.1021/acs.est.9b00006

Luo, C., Feng, M., Sharma, V. K., \& Huang, C. H. (2020a). Revelation of ferrate (VI) unimolecular decay under alkaline conditions: Investigation of involvement of $\mathrm{Fe}$ (IV) and $\mathrm{Fe}(\mathrm{V})$ species. Chemical Engineering Journal, 388, 124134. https://doi.org/10.1016/j.cej.2020.124134

Luo, H., Zeng, Y., Cheng, Y., He, D., \& Pan, X. (2020b). Recent advances in municipal landfill leachate: A review focusing on its characteristics, treatment, and toxicity assessment. Science of the Total Environment, 703, 135468. https://doi.org/10.1016/j.scitotenv.2019. 135468

Lv, D., Zheng, L., Zhang, H., \& Deng, Y. (2018). Coagulation of colloidal particles with ferrate (VI). Environmental Science: Water Research \& Technology, 4, 701-710. https:// doi.org/10.1039/C8EW00048D

Marrone, P. A. (2013). Supercritical water oxidation - Current status of full-scale commercial activity for waste destruction. Journal of Supercritical Fluids, 79, 283-288. https:// doi.org/10.1016/j.supflu.2012.12.020

Mojiri, A., Zhou, J. L., Ratnaweera, H., Ohashi, A., Ozaki, N., Kindaichi, T., \& Asakura, H. (2021). Treatment of landfill leachate with different techniques: An overview. Water Reuse, 11(1), 66-96. https://doi.org/10.2166/wrd.2020. 079

Moradnia, M., Panahifard, M., Dindarlo, K., Jamali, H. A. (2016). Optimizing potassium ferrate for textile 
wastewater treatment by RSM. Environmental Health Engineering and Management Journal, 3(3), 137-142. http://ehemj.com/article-1-194-en.html

Renou, S., Givaudan, J. G., Poulain, S., Dirassouyan, F., \& Moulin, P. (2008). Landfill leachate treatment: Review and opportunity. Journal of Hazardous Materials, 150(3), 468-493. https://doi.org/10.1016/j.jhazmat.2007.09.077

Rivas, F. J., Beltrán, F. J., Carvalho, F., \& Alvarez, P. M. (2005). Oxone-promoted wet air oxidation of landfill leachates. Industrial \& Engineering Chemistry Research, 44(4), 749-758. https://doi.org/10.1021/ie0401511

Rush, J. D., \& Bielski, B. H. J. (1989). Kinetics of ferrate (V) decay in aqueous solution: A pulse-radiolysis study. Inorganic Chemistry, 28(21), 3947-3951. https://doi.org/10. 1021/ic00320a004

Rush, J. D., Zhao, Z., \& Bielski, B. H. J. (1996). Reaction of ferrate(VI)/ferrate(V) with hydrogen peroxide and superoxide anion - A stopped-flow and premix pulse radiolysis study. Free Radical Research, 24, 187-198. https://doi. org/10.3109/10715769609088016

Scandelai, A. P. J., Cardozo, F. L., Martins, D. C. C., Freitas, T. K. F. D. S., Garcia, J. C., \& Tavares, C. R. G. (2018). Combined processes of ozonation and supercritical water oxidation for landfill leachate degradation. Waste Management, 77, 466-476. https://doi.org/10.1016/j.wasman. 2018.04.031

Schreyer, J. M., Thompson, G. W., \& Ockerman, L. T. (1950). Oxidation of chromium(III) with potassium ferrate(VI). Analytical Chemistry, 22, 1426-1427. https://doi.org/10. 1021/ac60047a022

Serpone, N., Horikoshi, S., \& Emeline, A. V. (2010). Microwaves in advanced oxidation processes for environmental applications. A brief review. Journal of Photochemistry and Photobiology c: Photochemistry Reviews, 11, 114131. https://doi.org/10.1016/j.jphotochemrev.2010.07.003

Sharma, V. K., Rendon, R. A., Millero, F. J., \& Vazquez, F. G. (2000). Oxidation of thioacetamide by ferrate(VI). Marine Chemistry, 70, 235-242. https://doi.org/10.1016/S03044203(00)00029-3

Srinu, N. S., Pydi, S. Y. (2001). Optimization for denitrification of wastewater using fluidized bed bioreactor by Taguchi method. International Journal of Biotechnology Applications, 3, 97-101. Available online: http://www.bioinfo.in/ contents.php?id=22

Sushma, K. M., \& Saroha, A. K. (2018). Performance of various catalysts on treatment of refractory pollutants in industrial wastewater by catalytic wet air oxidation: A review. Journal of Environmental Management, 228, 169188. https://doi.org/10.1016/j.jenvman.2018.09.003

Takeuchi, N., \& Yasuoka, K. (2021). Review of plasma-based water treatment technologies for the decomposition of persistent organic compounds. Japanese Journal of Applied Physics, 60, SA0801. https://doi.org/10.35848/1347-4065/ abb75d

Tejera, J., Miranda, R., Hermosilla, D., Urra, I., Negro, C., \& Blanco, A. (2019). Treatment of a mature landfill leachate: Comparison between homogenous and heterogenous photo-Fenton with different parameters. Water, 11, 1849. https://doi.org/10.3390/w11091849

Thomas, M., Barbusinski, K., Klis, S., Szpyrka, E., \& Chyc, M. (2018). Synthetic textile wastewater treatment using potassium ferrate(VI) - Application of Taguchi method for optimisation of experiment. Fibres \& Textiles in Eastern Europe, 3(129), 104-109. https://doi.org/10.5604/01. 3001.0011 .7313

Thomas, M., Kozik, V., Barbusiński, K., Sochanik, A., Jampilek, J., \& Bąk, A. (2020). Potassium ferrate (VI) as the multifunctional agent in the treatment of landfill leachate. Materials, 13, 5017. https://doi.org/10.3390/ma132 15017

Thomas, M., \& Zdebik, D. (2019). Treatment of real textile wastewater by using potassium ferrate(VI) and $\mathrm{Fe}(\mathrm{III}) /$ $\mathrm{H} 2 \mathrm{O} 2$. Application of Aliivibrio fischeri and Brachionus plicatilis Tests for Toxicity Assessment. Fibres \& Textiles in Eastern Europe, 27(135), 78-84. https://doi.org/10. 5604/01.3001.0013.074

Verma, M., \& Kumar, R. N. (2016). Can coagulation-flocculation be an effective pre-treatment option for landfill leachate and municipal wastewater co-treatment? Perspectives in Science, 8, 492-494. https://doi.org/10.1016/j. pisc.2016.05.005

Wang, S., Guo, Y., \& Chen, C. (2011). Supercritical water oxidation of landfill leachate. Waste Management, 31, 20272035. https://doi.org/10.1016/j.wasman.2011.05.006

Wang, S., Shao, B., Qiao, J., \& Guan, X. (2021). Application of $\mathrm{Fe}(\mathrm{VI})$ in abating contaminants in water: State of art and knowledge gaps. Frontiers of Environmental Science \& Engineering, 15, 80. https://doi.org/10.1007/ s11783-020-1373-3

Wang, K., Li, L., Tan, F., Wu, D. (2018a). Treatment of landfill leachate using activated sludge technology: A review. Archaea. Article id: 1039453https://doi.org/10.1155/ 2018/1039453

Wang, L., Lin, H., Dong, Y., \& He, Y. (2018b). Effects of cropping patterns of four plants on the phytoremediation of vanadium containing synthetic wastewater. Ecological Engineering, 115, 27-34. https://doi.org/10.1016/j.ecole ng.2018.01.008

Wei, N., Xu, D., Hao, B., Guo, S., \& Guo., Y., Wang, S. . (2021). Chemical reactions of organic compounds in supercritical water gasification and oxidation. Water Research, 190, 116634. https://doi.org/10.1016/j.watres. 2020.116634

Wei, Y.-L., Wang, Y.-S., \& Liu, C.-H. (2015). Preparation of potassium ferrate from spent steel pickling liquid. Metals, 5, 1770-1787. https://doi.org/10.3390/met5041770

Weingärtner, H., \& Franck, E. U. (2005). Supercritical Water as a Solvent. Angewandte Chemie International Edition, 44, 2672-2692. https://doi.org/10.1002/anie.200462468

Więckol-Ryk, A., Białecka, B., \& Thomas, M. (2020). Application of calcium peroxide as an environmentally friendly oxidant to reduce pathogens in organic fertilizers and its impact on phosphorus bioavailability. Archives of Environmental Protection, 46(4), 42-53. https://doi.org/10. 24425/aep.2020.135763

Wiszniowski, J., Robert, D., Surmacz-Gorska, J., Miksch, K., \& Weber, J. V. (2006). Landfill leachate treatment methods: A review. Environmental Chemistry Letters, 4, 51-61. https://doi.org/10.1007/s10311-005-0016-Z

Xu, X. Y., Zeng, G. M., Peng, Y. R., \& Zeng, Z. (2012). Potassium persulfate promoted catalytic wet oxidation of fulvic acid as a model organic compound in landfill leachate 
with activated carbon. Chemical Engineering Journal, 200-202, 25-31. https://doi.org/10.1016/j.cej.2012.06.029

Yadav, J. S., \& Dikshit, A. K. (2017). Stabilized old landfill leachate treatment using electrocoagulation. Environment Asia, 10, 25-33. https://doi.org/10.14456/ea.2017.4

Zhai, Y., Zhu, L., Zhu, Y., Peng, Ch., Wang, T., Liu, X., Li, C., \& Zeng, G. (2016). Simultaneous total organic carbon and humic acid removals for landfill leachate using subcritical water catalytic oxidation based on response surface methodology. Water, Air \& Soil Pollution, 227, 273. https://doi. org/10.1007/s11270-016-2977-X

Zhang, Y., Luo, Z., Qu, Y., Lin, Y., Huang, Y., \& Zheng, Z. (2014). Pretreatment of landfill leachate by potassium
ferrate(VI). Chinese Journal of Environmental Engineering, 8(6), 2451-2455.

Zhou, H., Zhang, H., He, Y., Huang, B., Zhou, C., Yao, G., \& Lai, B. (2021). Critical review of reductant-enhanced peroxide activation processes: Trade-off between accelerated $\mathrm{Fe}^{3+} / \mathrm{Fe}^{2+}$ cycle and quenching reactions. Applied Catalysis b: Environmental, 286, 119900. https://doi.org/ 10.1016/j.apcatb.2021.119900

Publisher's Note Springer Nature remains neutral with regard to jurisdictional claims in published maps and institutional affiliations. 